\title{
The Effects of Sida corymbosa Leaf Extract Against Abnormal Bilirubin and Total Protein in Albino Rats by Carbon Tetrachloride $\left(\mathrm{CCl}_{4}\right)$
}

\author{
Dike Charles Chijioke ${ }^{1, *}$, Ezeonu Francis Chukwuemeka ${ }^{2}$, Maduka Hugh Clifford Chima ${ }^{1}$, \\ Ezeokafor Emmanuel Nonso ${ }^{3}$, Okpogba Aloysius Ngozika ${ }^{1}$, Oguazu Chinenye Enoch ${ }^{2}$, \\ Eyeghre Onoriode Akpoghene ${ }^{3}$, Asebioyo Sunday Jacob $^{4}$ \\ ${ }^{1}$ Department of Human Biochemistry, Faculty of Basic Medical Sciences, College of Health Sciences, Nnamdi Azikiwe University, Nnewi \\ Campus, Anambra State, Nigeria \\ 2 Department of Applied Biochemistry, Faculty of Biosciences, Nnamdi Azikiwe University, Awka, Anambra State, Nigeria \\ ${ }^{3}$ Department of Human Physiology, Faculty of Basic Medical Sciences, College of Health Sciences, Nnamdi Azikiwe University, Nnewi \\ Campus, Anambra State, Nigeria \\ ${ }^{4}$ Department of Anatomy, Faculty of Basic Medical Sciences, College of Health Sciences, Nnamdi Azikiwe University, Nnewi Campus, \\ Anambra State, Nigeria
}

\section{Email address:}

cc.dike@unizik.edu.ng (D. C. Chijioke), fc.ezeonu@unizik.edu.ng (E. F. Chukwuemeka), hcc.maduka@unizik.edu.ng (M. H. C. Chima), emmaezeokafor@gmail.com (E. E. Nonso),okpogba4real@yahoo.com (O. A. Ngozika), ce.oguazu@unizik.edu.ng (O. C. Enoch), eyeghreo@yahoo.com (E. O. Akpoghene), sundayjacob888@gmail.com (A. S. Jacob)

${ }^{*}$ Corresponding author

\section{To cite this article:}

Dike Charles Chijioke, Ezeonu Francis Chukwuemeka, Maduka Hugh Clifford Chima, Ezeokafor Emmanuel Nonso, Okpogba Aloysius Ngozika, Oguazu Chinenye Enoch, Eyeghre Onoriode Akpoghene, Asebioyo Sunday Jacob. The Effects of Sida corymbosa Leaf Extract Against Abnormal Bilirubin and Total Protein in Albino Rats by Carbon Tetrachloride $\left(\mathrm{CCl}_{4}\right)$. Journal of Diseases and Medicinal Plants. Vol. 6, No. 2, 2020, pp. 39-46. doi: 10.11648/j.jdmp.20200602.12

Received: January 30, 2020; Accepted: February 13, 2020; Published: June 15, 2020

\begin{abstract}
The Sida corymbosa plant has been used for centuries in traditional medicine in different countries for prevention and treatment of different diseases such as liver and cardiac diseases. This work aimed at investigating if Sida corymbosa ethanolic leaf extract has preventive and therapeutic effects against abnormal serum bilirubin and total protein in Albino rats by carbon tetrachloride $\left(\mathrm{CCl}_{4}\right)$. This study took place at Nnamdi Azikiwe University, Nnewi Campus, Anambra State. The rats were grouped into those given 5000, 3000 and $1000 \mathrm{mg} / \mathrm{kgbw}$ of the extract before and after $\mathrm{CCl}_{4}$ administration from $7 \mathrm{~d}$ to $28 \mathrm{~d}$, those injected $\mathrm{CCl}_{4}$ only which stayed from $7 \mathrm{~d}$ to $28 \mathrm{~d}$ and those without $\mathrm{CCl}_{4}$ and extract. Male Albino rats weighing 170-190 g were used. Injection of $\mathrm{CCl}_{4}(0.4 \mathrm{ml} / \mathrm{kgbw}$ i.p) was done using olive as vector before and after oral administration of the Sida corymbosa extract. Serum bilirubin was estimated using Powel's method while serum total protein was estimated using the Biuret method. Results were analyzed statistically using SPSS statistical software version 21. Analysis done so far revealed that serum bilirubin of rats injected $\mathrm{CCl}_{4}$ without extract administration (negative control) was significantly higher $(\mathrm{P}<0.05)$ than other groups, those administered 5000, 3000 and $1000 \mathrm{mg} / \mathrm{kgbw}$ of extract before and after $\mathrm{CCl}_{4}$ injection and those without $\mathrm{CCl}_{4}$ nor extract (positive control). The reverse was the case for serum total protein, suggesting protective and therapeutic potentials of the extract. Sida corymbosa ethanolic leaf extract may, therefore, has some protective and therapeutic effects against abnormal serum bilirubin and total protein synthesis in Albino rats by $\mathrm{CCl}_{4}$ thereby improving the liver function.
\end{abstract}

Keywords: Bilirubin level, Total Protein Determination, Administration of Sida corymbosa, Carbon Tetrachloride Administration 


\section{Introduction}

The liver is one of the largest and most important organs in the body. It plays a pivotal role in regulating various physiological processes in the body [1-3]. Metabolism of biochemical molecules like protein, carbohydrates, lipids, bilirubin, minerals and vitamins takes place in the liver and any alteration in these molecules will result in malfunctioning of the liver. Liver illness is among the most prevalent illness and one of the largest health challenges of the world recently [4]. It has been reported that xenobiotics like carbon tetrachloride, environmental pollutants and microbial infiltration from ingestion or infection can destroy the liver [5-6]. Carbon tetrachloride $\left(\mathrm{CCl}_{4}\right)$ has been used in many research as a model for inducing minor and severe liver injuries as a result of oxidative stress induced. Bilirubin and protein are among the biomolecules used in accessing the health status of the liver [4]. Elevated bilirubin level has been reported to be one of indicators of liver toxicity [3]. Plants are basic source of knowledge of modern medicine which reflects recognition of the validity of many traditional claims regarding the value of natural products in health care system [7].

Herbal remedies have been used over time, even among educated people in most parts of Africa with success. Traditional medicine existed before the introduction of synthetic drugs and it is older than civilization [1-2]. A number of orthodox drugs have been isolated from plants [8]. Man has over the time depended on plants for survival, particularly for food and medicinal purposes [7]. He acquired the knowledge of usefulness of plants by trial and error and passed on the information from generation to generation without documentation. Sida species are one of the ethnomedicinally important geniuses of plants which are used in many local villages in the treatment of various diseases [9]. About 30 species of Sida were found in Africa, 35 in Austrialia, \pm 110 in North Central and South Africa [8]. The chemical profiles of Sida plants have differences; therefore, differences in pharmacological activities may be expected. Different species of sida are used for the preparation of the same medicine at different places [10].

Sida corymbosa is one of the species of sida plants found in most parts of Eastern, Western and Northern Nigeria where it is claimed to be used in treating many diseases such as ulcer, dysentery, diarrhoea, liver disorders, malaria, diabetics and inducing labor. All parts of this plant, including leaves, bark, root, seeds and flowers are used in folkloric medicine [11]. There has been several reported cases of using Sida corymbosa leaf extracts in the treatment of liver diseases such as jaundice [1-3]. Literature abound on the hemostatic, antibleeding, antiulcer and antirust properties of S. corymbosa leaf extracts but there is still scanty information on the protective and curative potentials of $S$. corymbosa extracts on liver diseases. There have been claims by some traditional medical practitioners on the usefulness of Sida corymbosa in treating and managing liver diseases such as jaundice, without scientific validation. This work was therefore justified by investigating the protective and curative properties of Sida corymbosa ethanolic leaf extract against $\mathrm{CCl}_{4}$-induced abnormal serum bilirubin and total protein level.

\section{Materials and Methods}

All chemicals used in this work were of analytical grade and purchased from British Drug House Ltd., Poole, England, through her sales Representative in Ikeja-Lagos State, Nigeria. All reagent kits used were obtained from Randox Laboratories Ltd., United Kingdom, through her sales representative in Ikela-Lagos State, Nigeria. These include, $\mathrm{CCl}_{4}$, absolute ethanol, diethyl ether, kits for serum bilirubin and total protein.

\subsection{Sample Collection}

The plants were obtained from Okofia-Otolo, Nnewi, in Nnewi-North Local Government of Anambra State, Nigeria. It has been identified in the earlier report [1].

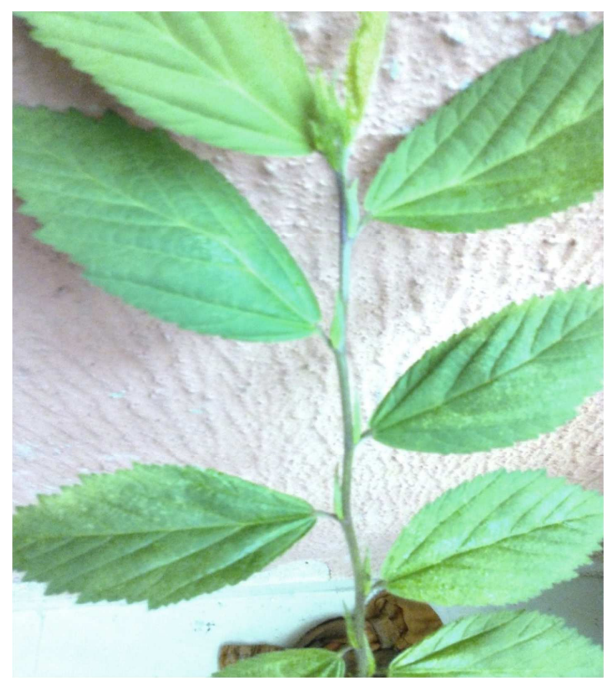

Figure 1. Photograph of Sida corymbosa.

\subsection{Sample Preparation}

The plant leaves were prepared using a known standard method as described [12]. The leaves of Sida corymbosa plants were washed with distilled water, air dried at room temperature and powdered using a blender. The ethanol extract were obtained by soaking $25 \mathrm{~g}$ of the dried leaves in a round bottom flask containing $200 \mathrm{ml}$ of absolute ethanol $(98 \%)$ for $48 \mathrm{~h}$ with occasional shaking at room temperature. The ethanolic extract was filtered through $40 \mathrm{~mm}$ Whatman filter paper and evaporated using rotary evaporator (Model: TT52, USA) at $65^{\circ} \mathrm{C}$. The crude extract was dried using oven (Model: TT-9023A, China) at $42^{\circ} \mathrm{C}$.

\subsection{Ethical Approval}

All methods used in the animal research complied with standards for use and care of experimental animals and were 
approved by the Animal Ethical Committee of Faculty of Basic Medical Sciences, College of Health Sciences, Nnamdi Azikiwe University, Nnewi Campus, Anambra State, Nigeria. The ethical approval certificate is hereby attached to this work.

\subsection{Animal Handling and Experimental Design}

The acute toxicity studies $\left(\mathrm{LD}_{50}\right)$ had earlier been determined to be above $5000 \mathrm{mg} / \mathrm{kgbw}$ which have been confirmed [1]. A total of 160 male-Albino rats of about 12 weeks old (170-190 g) which were maintained at Animal Unit of Faculty of Basic Medical Sciences, College of Health Sciences, Nnamdi Azikiwe University, Nnewi Campus, Anambra State, Nigeria, were used in this study. The rats underwent acclimatization for three weeks in animal cages under the same temperature and humidity condition. Rats were fed on commercial feed (Vital growers) obtained from Gland Cereals Ltd., a subsidiary of UAC Nigeria PLC., Zawana, Jos, Plateau State, Nigeria, through her sales representative at Edoezemewi Road, Nnewi, Anambra State. Animal handling was done inline with guidelines given by WHO and Indian National Science Academy (INSA), New Delhi, India [7-8]. The rats were given water and feed ad libitum.

Hundred and sixty rats were grouped into 32 with each group containing five rtas. Twelve groups were administered Sida corymbosa ethanolic leaf extract via oral route using oral canular at 5000, 3000 and $1000 \mathrm{mg} / \mathrm{kgbw}$ for seven days, fourteen days, twenty one days and twenty eight days afterwhich $0.4 \mathrm{ml} / \mathrm{kgbw}$ of $\mathrm{CCl}_{4}$ was injected into each rat intraperitoneally (i.p) for four days using olive oil as vector in the ratio of 50: $50 \mathrm{v} / \mathrm{v}$. Four groups of rats containing five rats ech were given only feed and water (positive control or normal rats) for seven days, fourteen days, twenty one days and twenty eight days. Another four groups were administered 0.4 $\mathrm{ml} / \mathrm{kgbw}$ of $\mathrm{CCl}_{4}$ only (i.p) and left to stay for seven days, fourteen days, twenty one days and twenty eight days (negative control or untreated group). Another 12 groups of rats were each administered $0.4 \mathrm{ml} / \mathrm{kgbw}$ of $\mathrm{CCl}_{4}$ (i.p). After this, the rats were administered 5000, 3000 and 1000 $\mathrm{mg} / \mathrm{kgbw}$ of Sida corymbosa ethanolic leaf extract for seven days, fourteen days, twenty one days and twenty eight days. The rats were anaesthetized using diethyl ether at the end of the treatment periods and blood samples taken under dark environment via ocular puncture using heparin specimen bottles and heparinized capillary tubes. Serum was separated by centrifugation at $3000 \mathrm{rpm}$ for $15 \mathrm{~min}$ at room temperature using Ultra Modern Centrifuge Machine (Model: 800D, China) and stored in a refrigerator (Model: HTF-319, China) at $+8^{\circ} \mathrm{C}$ for further analysis.

\subsection{Determination of Serum Bilirubin}

Serum total and conjugated bilirubin were determined using Powel's method [13].

Principle

Conjugated bilirubin reacts with diazotized sulphanilic acid in alkaline medium to form a blue coloured complex whose absorbance is measured spectrophotometrically or colorimetrically. Total bilirubin is determined in the presence of caffeine, which releases albumin bound bilirubin by reaction with diazotized sulphanilic acid.

Procedure:

For total bilirubin, reagent one $(200 \mu \mathrm{l})$, reagent two $(50 \mu \mathrm{l}$ and reagent three $(1000 \mu \mathrm{l})$ were mixed with $200 \mu \mathrm{l}$ of various samples in the respective test tubes. These were incubated at room temperature for ten minutes. The same was done for blank except that reagent two and serum were not added to the blank. This was followed by the addition of reagent four (1000 $\mu 1)$, mixing and incubation for $30 \mathrm{~min}$ at room temperature and absorbance taken at $530 \mathrm{~nm}$ spectrophotometrically using UV-VIS spectrophotometer (Model: $721 \mathrm{G}$, China)

Calculation:

Concentration of serum total bilirubin=10.8 X ATB $(\mathrm{mg} / \mathrm{dl})$

Where $\mathrm{ATB}=\mathrm{Absorbance}$ of total bilirubin

For conjugated bilirubin, reagent one $(200 \mu \mathrm{l})$, reagent two $(50 \mu \mathrm{l})$ and $0.9 \% \mathrm{NaCl}(2 \mathrm{ml})$ were mixed with $200 \mu \mathrm{l}$ of various samples in the respective test tubes. These were incubated at room temperature for ten minutes. The same was done for the blank except that ragent two and serum were not added to the blank. The absorbance was taken at $530 \mathrm{~nm}$ against blank spectrophotometrically using UV-VIS spectrophotometer (Model: 721G, China).

Calculation:

$$
\text { Concentration of serum conjugated bilirubin=14.4 X ACB (mg/dl) }
$$

Where $\mathrm{ACB}=\mathrm{Absorbance}$ of conjugated bilirubin

Serum unconjugated bilirubin $=\mathrm{TB}-\mathrm{CB}$

Where $\mathrm{TB}=$ Total bilirubin

$\mathrm{CB}=$ Conjugated bilirubin

\subsection{Determination of Serum Total Protein}

This was done using biuret method [13].

Principle:

The principle is based on the interaction of cupric ions with protein peptide bonds in alkaline medium resulting in the formation of a coloured complex whose absorbance is taken at $520 \mathrm{~nm}$ spectrophotometrically using UV-VIS spectrophotometer (Model: 721G, China).

Procedure:

Twenty microlitres each of distilled water, serum and bovine serum albumin (BSA) standard was added into test tubes for reagent blank, test and total protein standard. This was followed by the addition of one mill of biuret reagent (reagent one) to all the test tubes. This was incubated for 30 min at room temperature. After this, absorbance was taken against reagent blank spectrophotometrically at $520 \mathrm{~nm}$. 
Calculation:

Conc of serum total protein $=$ Abs test - Abs blank $/$ Abs STD - Abs blank X Conc of STD $(6 \mathrm{mg} / \mathrm{dl})$

Where STD $=$ Standard

Conc $=$ Concentration

Abs $=$ Absorbance

\subsection{Statistical Analysis}

The results obtained were expressed as mean \pm standard deviation of triplicate determination. One way analysis of ANOVA was used to analyze results using SPSS statistical software version 21 . Test for significance was done at 0.05 level of significance.

\section{Results}

The results of the serum bilirubin (Total, conjugated and unconjugated bilirubins) of albino rats given Sida corymbosa ethanolic leaf extract before and after injecting $\mathrm{CCl}_{4}$ are hereby presented in figures 2-7. In all instances of significant differences, the levels of total bilirubin (TB), conjugated bilirubin (CB) and unconjugated bilirubin (UCB) were significantly higher $(\mathrm{P}<0.05)$ in untreated group of rats $(3.14-$ $4.92 \mathrm{mg} / \mathrm{dl}$, for TB, $2.16-3.23 \mathrm{mg} / \mathrm{dl}$, for CB and $1.10-1.69$ for UCB) than in those groups given the extract at 5000 $\mathrm{mg} / \mathrm{kgbw}, 3000 \mathrm{mg} / \mathrm{kgbw}$ and $1000 \mathrm{mg} / \mathrm{kgbw}$ before and after injecting $\mathrm{CCl}_{4}$ and positive control (normal rats) $(1.32-1.31$ for TB, $1.17-1.16$ for $\mathrm{CB}$ and $0.15-0.16$ for UCB. The highest decrease in values for total bilirubin among the treated groups was witnessed at 28 days of treatment in those given $5000 \mathrm{mg} / \mathrm{kg}$ of the extract followed by those given 3000 $\mathrm{mg} / \mathrm{kg}$ while those given $1000 \mathrm{mg} / \mathrm{kgbw}$ showed the least decrease in total bilirubin at 28 days of treatment for both studies.

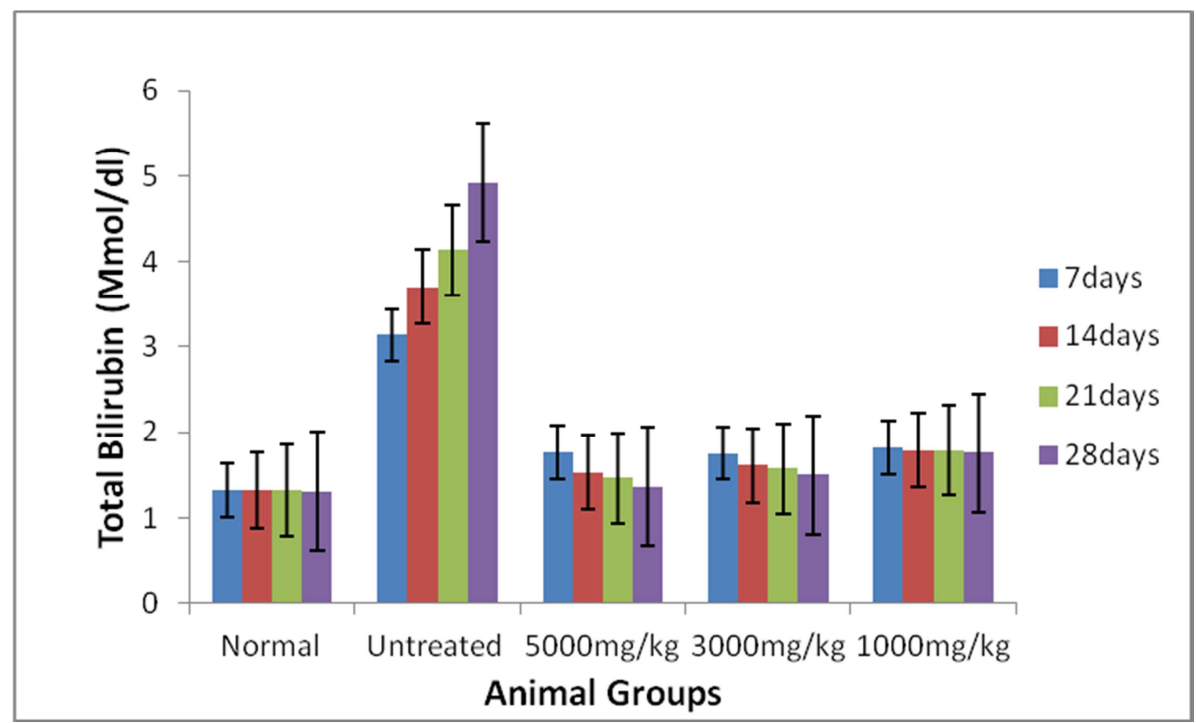

Figure 2. Graph of mean serum total bilirubin levels of rats given Sida corymbosa ethanolic leaf extract before injecting $\mathrm{CCl}_{4}$.

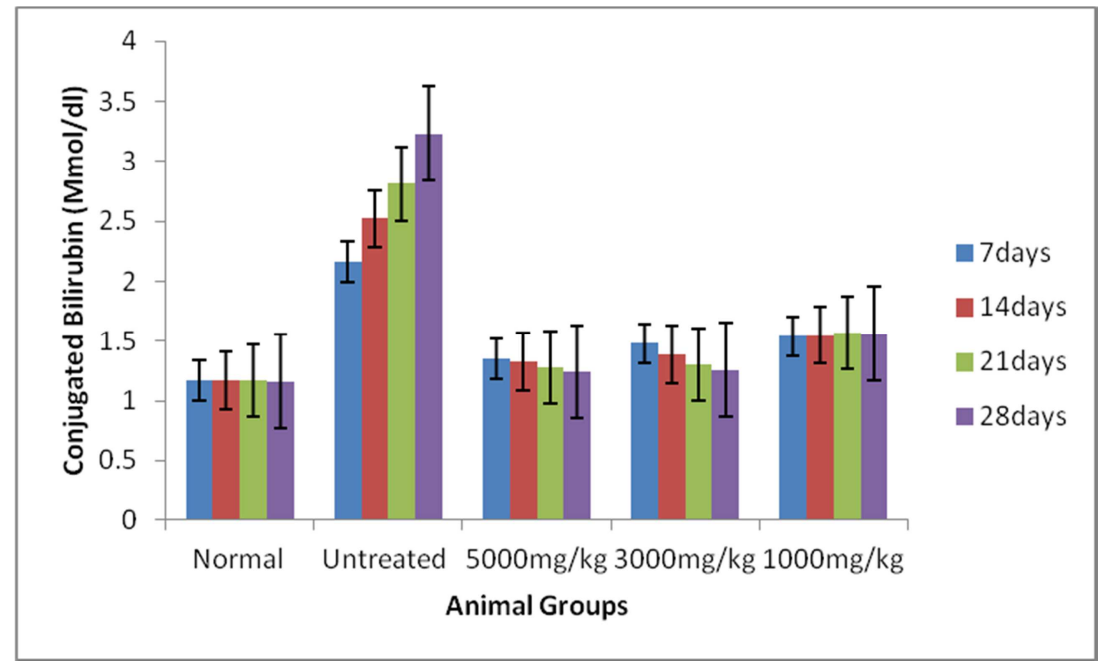

Figure 3. Graph of mean serum conjugated bilirubin levels of rats given Sida corymbosa ethanolic leaf extract before injecting $\mathrm{CCl}_{4}$. 


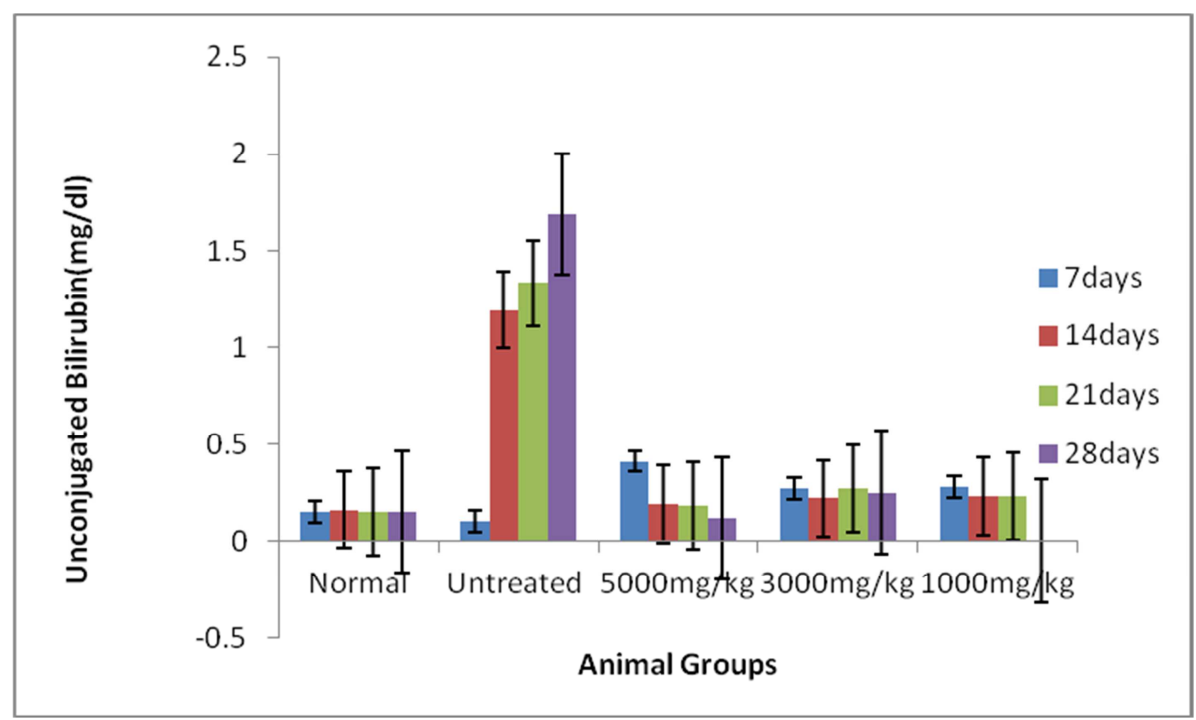

Figure 4. Graph of mean serum unconjugated bilirubin levels of rats given Sida corymbosa ethanolic leaf extract before injecting $\mathrm{CCl}_{4}$.

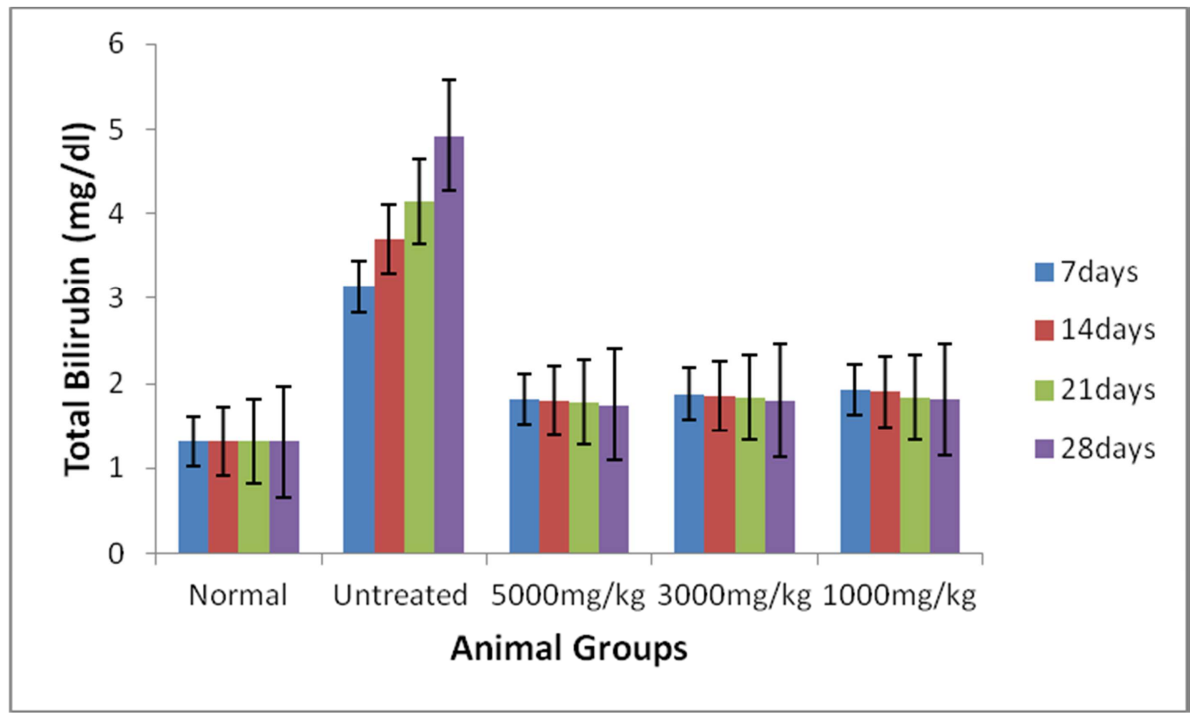

Figure 5. Graph of mean serum total bilirubin levels of rats given Sida corymbosa ethanolic leaf extract after injecting $\mathrm{CCl}_{4}$.

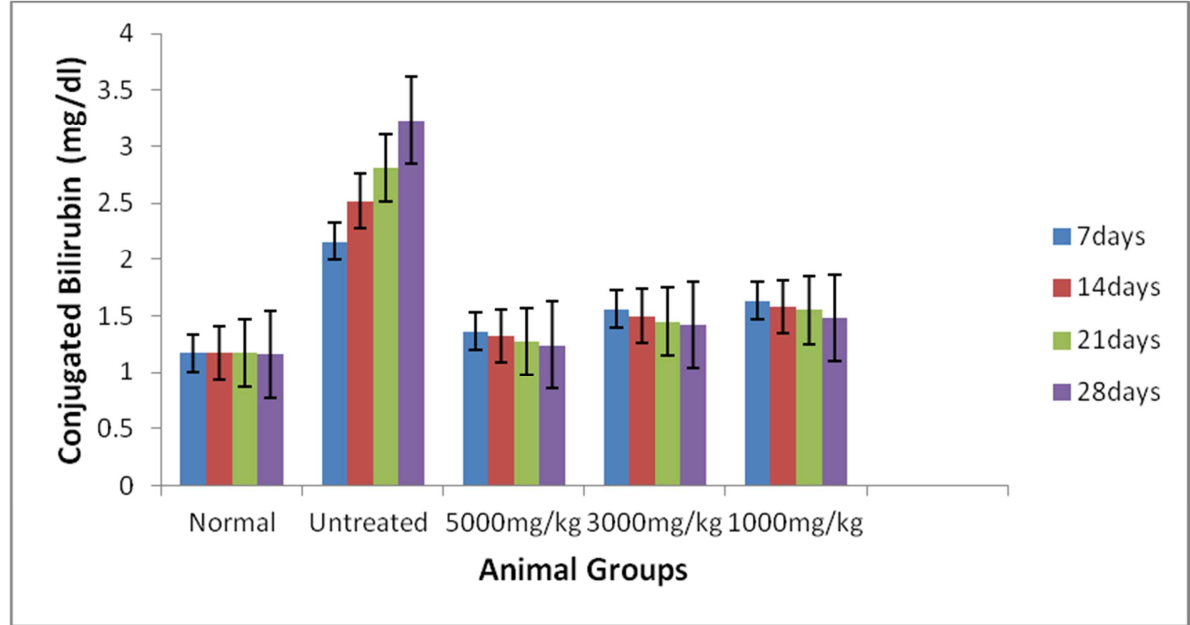

Figure 6. Graph of mean serum conjugated bilirubin levels of rats given Sida corymbosa ethanolic leaf extract after injecting $\mathrm{CCl}_{4}$. 


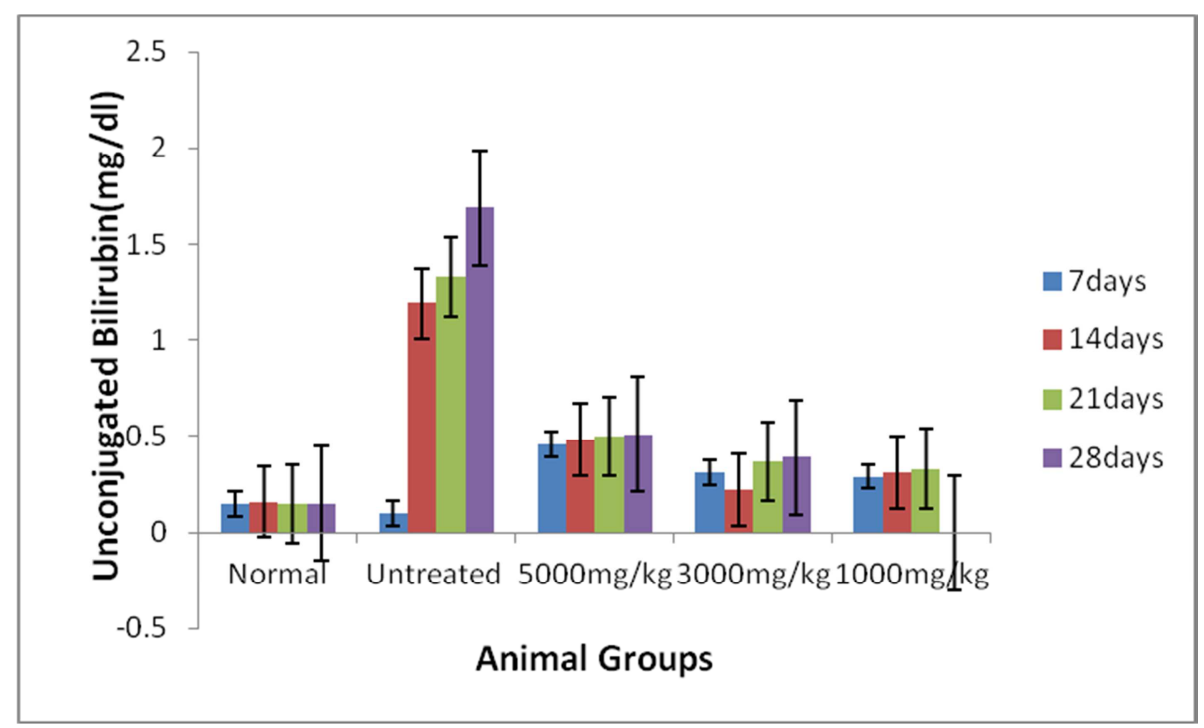

Figure 7. Graph of mean serum unconjugated bilirubin levels of rats given Sida corymbosa ethanolic leaf extract after injecting CCl $_{4}$.

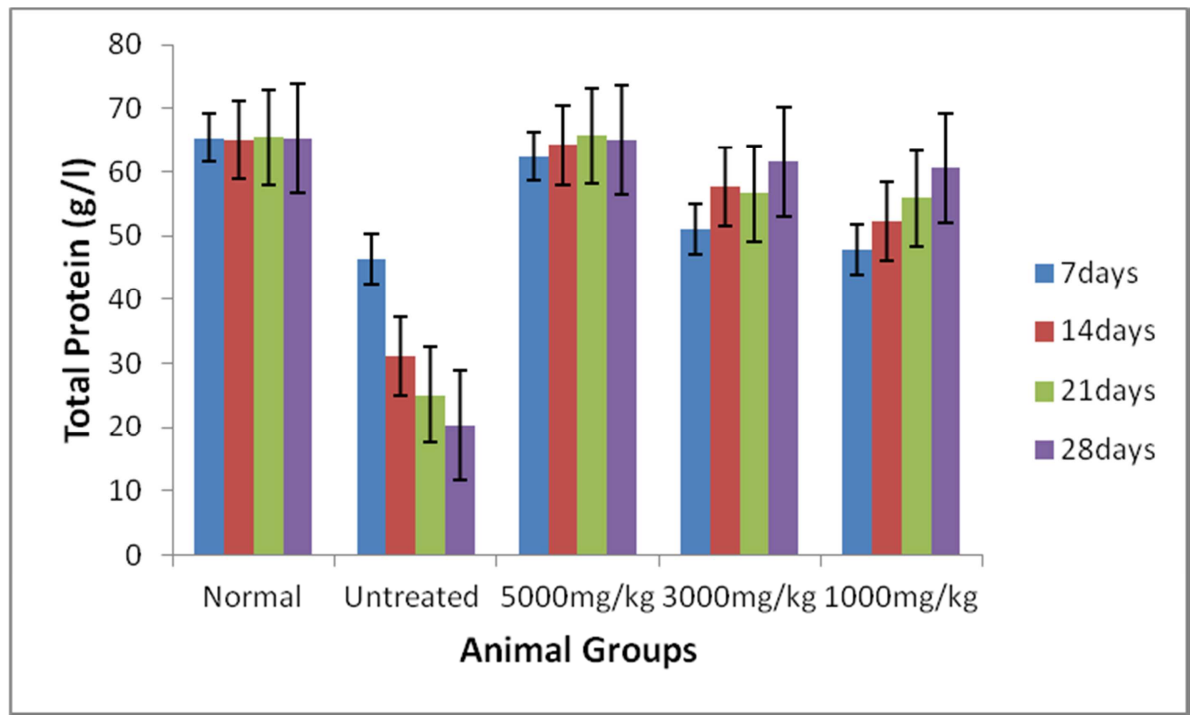

Figure 8. Graph of mean serum total protein levels of rats given Sida corymbosa ethanolic leaf extract before injecting $\mathrm{CCl}_{4}$.

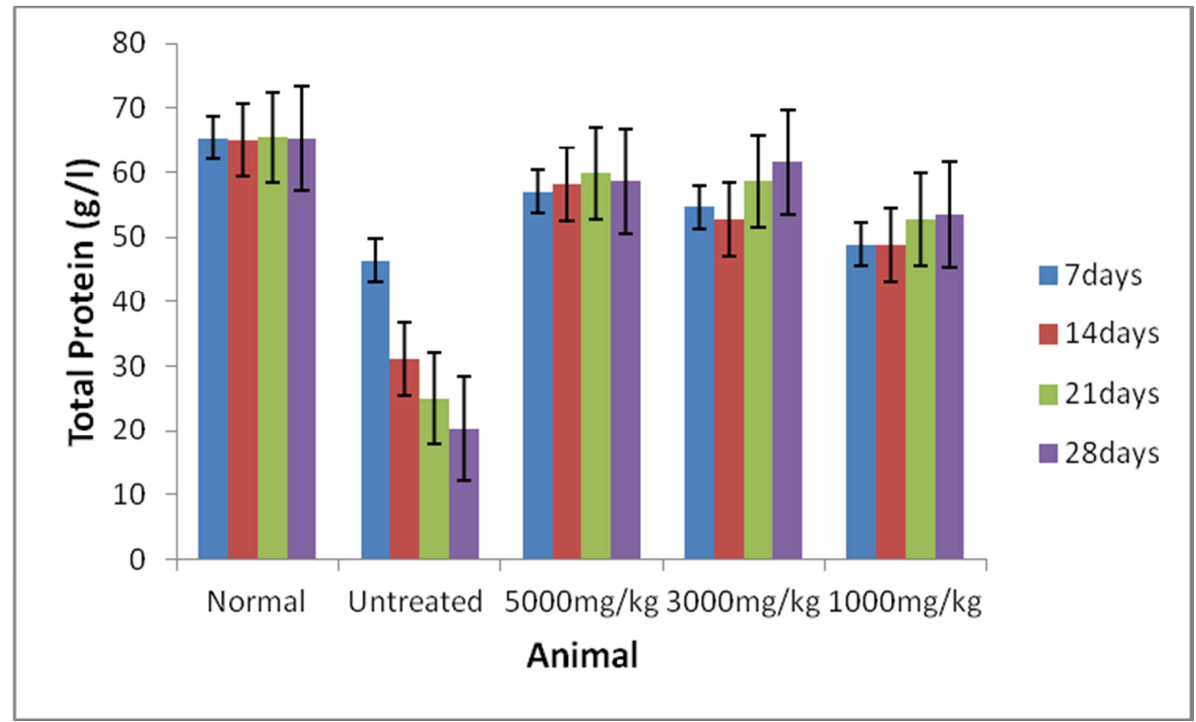

Figure 9. Graph of mean serum total protein levels of rats given Sida corymbosa ethanolic leaf extract after injecting $\mathrm{CCl}_{4}$. 
The results of serum total protein level of rats given Sida corymbosa ethanolic leaf extract before and after injecting $\mathrm{CCl}_{4}$ are hereby presented in figures 8-9. Results revealed that serum total protein was significantly $(\mathrm{P}<0.05)$ lower in untreated rats $(46.39 \mathrm{~g} / \mathrm{l} \pm 0.90-20.24 \mathrm{~g} / \mathrm{l} \pm 0.96)$ than those given $5000 \mathrm{mg} / \mathrm{kgbw}, 3000 \mathrm{mg} / \mathrm{kgbw}, 1000 \mathrm{mg} / \mathrm{kgbw}$ and positive control groups from $7-28$ days of treatment for both those administered the extract before and after $\mathrm{CCl}_{4}$ injection (Protective and Curative studies). There was no significant difference in the values of total protein between those given $5000 \mathrm{mg} / \mathrm{kgbw}$ of the extract and positive control groups $(64.98-65.38 \mathrm{~g} / \mathrm{l})$ from $7-28$ days for both protective and curative studies. The total protein for those given 5000 $\mathrm{mg} / \mathrm{kgbw}$ of the extract was significantly higher $(\mathrm{P}<0.05)$ than those given 3000 and $1000 \mathrm{mg} / \mathrm{kgbw}$ for both protective and curative studies (those administered the extract before and after $\mathrm{CCl}_{4}$ administration.

\section{Discussion}

This work involved investigations to finding out if Sida corymbosa ethanolic leaf extract have potentials to protect and reverse abnormal bilirubin and total protein in blood of male-Albino rats at different doses. The findings of this work revealed significant increase $(\mathrm{P}<0.05)$ in serum bilirubins (Total, conjugated and unconjugated bilirubins) levels of rats administered $\mathrm{CCl}_{4}$ without extract administration (negative control or untreated rats) against rats in positive control or normal rats and those administered 5000, 3000 and 1000 $\mathrm{mg} / \mathrm{kgbw}$ of the extract before $\mathrm{CCl}_{4}$ administration from seven to twenty eight days. This suggests protection of the treated rats against elevated serum bilirubin. This agrees with smilar findings of [9]. Serum bilirubin is one of the biochemical-non enzyme biomarkers used in assessing the functional status of the liver. Elevation of conjugated bilirubin in serum is an indication that bile is not being properly excreted and may cause obstruction in the bile duct [4]. The greatest decrease in serum bilirubin, which was witnessed in rats administered $5000 \mathrm{mg} / \mathrm{kgbw}$ of the extract before administering $\mathrm{CCl}_{4}$ at 28 days may be an indication of dose and time dependent effect with $5000 \mathrm{mg} / \mathrm{kgbw}$ being better than 3000 and $1000 \mathrm{mg} / \mathrm{kgbw}$. Similar findings have been reported [10-11].

The significant increase also witnessed in serum bilirubins of negative control groups from seven to twenty eight days against those of rats administered $\mathrm{CCl}_{4}$ before administration of 5000,3000 and $1000 \mathrm{mg} / \mathrm{kgbw}$ of the extract and those of positive control groups also suggests that the extract may have reversed elevated serum bilirubin caused as a result of $\mathrm{CCl}_{4}$ administration, hence, improvement on the liver functions. Similar findings have been reported [12-15]. The highest decrease in serum total and unconjugated bilirubins witnessed in rats administered $5000 \mathrm{mg} / \mathrm{kgbw}$ against those administered 3000 and $1000 \mathrm{mg} / \mathrm{kgbw}$ from seven to twenty eight days after $\mathrm{CCl}_{4}$ administration again indicates dose and time dependent effects as $5000 \mathrm{mg} / \mathrm{kgbw}$ may be better than 3000 and 1000 $\mathrm{mg} / \mathrm{kgbw}$ of the extract for the treatment of elevated bilirubin in blood of Albino rats caused by $\mathrm{CCl}_{4}$.

However, the results of serum total protein assay carried out indicated higher serum total protein levels in both rats administered $\mathrm{CCl}_{4}$ before extract administration and those administered $\mathrm{CCl}_{4}$ after extract administration at 5000 $\mathrm{mg} / \mathrm{kgbw}, 3000 \mathrm{mg} / \mathrm{kgbw}, 1000 \mathrm{mg} / \mathrm{kgbw}$ and positive control than those administered $\mathrm{CCl}_{4}$ only, which showed decreased serum total protein level. This suggests protection and reversal of abnormal protein synthesis by Sida corymbosa ethanolic leaf extract against $\mathrm{CCl}_{4}$-induced abnormal protein synthesis. Similar assertions have been made [4]. Liver toxicity can lead to decreased protein synthesis and therefore, decreased level of total protein [1]. Those administered $5000 \mathrm{mg} / \mathrm{kgbw}$ of the extract have higher level of serum total protein than those administered 3000 and $1000 \mathrm{mg} / \mathrm{kgbw}$ of the extract, meaning that prevention and treatment against abnormal protein synthesis using the extract may be dependent on dosage and time frame, the best dose could be $5000 \mathrm{mg} / \mathrm{kgbw}$. This assertion is collerborated by the similar findings reported earlier [12-13]. Low level of total protein in blood is one of the indicators of liver damage. Carbon tetrachloride have been reported to cause decreased total protein synthesis, thereby resulting in hypoproteinaemia [1-2]. Protein plays significant role in tissue building and maintainance of cellular functions.

\section{Conclusion}

Results so far analyzed have clearly demonstrated that Sida corymbosa ethanolic leaf extract may have both protective and therapeutic effects against abnormal serum bilirubin and total protein in Albino rats caused by $\mathrm{CCl}_{4}$ administration which may be dependent on dose and duration. The best dose could be $5000 \mathrm{mg} / \mathrm{kgbw}$ at 28 days of treatment.

\section{References}

[1] Dike, C. C., F. C, Ezeonu, H. C. C. Maduka, E. N. Ezeokafor, C. E. Oguazu (2018). Hepatotherapeutic potentials of Sida corymbosa (Wire weed) ethanolic leaf extract on carbon tetrachloride $\left(\mathrm{CCl}_{4}\right)$-induced acute hepatotoxicity in male Albino rats. European Journal of Pharmaceutical and Medical Research 5, 146-155.

[2] Dike, C C., F. C. Ezeonu, H. C. C. Maduka, E. N. Ezeokafor C. E. Oguazu (2018). Hepatoprotective potentials of Sida corymbosa (Broom weed) ethanolic leaf extract against carbon tetrachloride $\left(\mathrm{CCl}_{4}\right)$-induced acute hepatotoxicity in male Albino wistar rats. Journal of Pharmacognosy and Phytochemistry 7, 2166-2177.

[3] Dike, C C, F. C. Ezeonu, H. C. C. Maduka, E. N. Ezeokafor (2018). Phytochemical and elemental analysis of Sida corymbosa (Broom weed or Wire weed) leaf and root extract. Chemical Science Journal 24, 1-9.

[4] WHO, (2004). Recommendations for the preparation, characterization and establishment of international and other biological reference standards. Technical Report: Series 932. 
[5] Jamilar, M. H. (2014). Hibiscus sabdarriffa calyx extract alleviate hepatotoxicity induced by carbon tetrachloride on male Albino rats. Nature Science 12, 111-120.

[6] Nasir, A, M., G. R. A. Abubakar, A. Shehu, B. K (2018). Toge Hepatoprotective effect of the aqueous extract of Andrographics paniculat against carbon tetrachloride-induced hepatotoxicity in rats. Nigerian Journal of Basic and Applied Sciences 21, 45-54.

[7] Okonkwo, O. J. O., H. C. C. Maduka, C. C. Dike, S. O. Maduka, V. Oguaka, C. M. Iketuonye (2018). The effect of Dacroydes edulis (African Pear) pulp oil extract on serum lipid parameters in male Albino Wistar rats. Journal of Applied Life Sciences International 17, 1-8.

[8] Kebe, E. O., U. Gabriel, C. Kelechi, O. I. Anozeng (2015). The effect of Sida acuta on glycogen profile of adult Wistar rat. Global Journal of Biology, Agriculture and Health Sciences 4, 52-55.

[9] Kelechi, C. U., E. O. Kebe, O. A. Amabe, U. Gabriel (2014). Extract of Sesamum indicum seeds on the glycogen profile of the liver of adult Wistar rats. Journal of Biology, Agriculture and Healthcare 4, 174-178.

[10] Arici, O. F. and N. Cetin (2011). Protective role of ghrelin against carbon tetrachloride (CCl4)- induced coagulation disturbances in rats. Regul Pept 166, 139-142.

[11] Maduka, H. C. C., A. A. Maduka, C. U. Aguoru, A. Myke-Mbata, J. O. Ikwue, A. N. Okpogba, C. E. Ugwu, C. C.
Dike, P. N. Ogueche, D. O. Ochalefu, U. Nath, J. Yakubu, E. Shatu (2017a). Phytochemical screening, spectrophtoometric determination of total carotenoids, chlorophyll $a$ and $b$ components of Crateva adansonii (Three-leaf Plant). Journal of Advances in.

[12] Maduka, H. C. C., Ugwu C. E., Dike, C. C., Okpogba, A. N., Ogueche, P. N., Ali, M. S., Bakare, S. S. and Tino, J. (2017b). In vitro free radical scavenging and antioxidant activities of aqueous extracts of Cateva adansonii (Three leaf plant). Journal of Advances in Medical and Pharmaceutical Sciences 15 (4): $1-8$.

[13] H. C. C. Maduka, E. I. Akubugwo, O. Olorunipe, Okpogba, A. N., Maduka, A. A., Ayuru, C. U., Ugwu, C. E., Dike, C. C. and Ogueche, P. N. (2016). Elemental composition and phytochemical screening of aqueous leaf extract and stem bark extract of Crateva adansonii. International Journal of Biochemistry Research and Review 10, 1-7.

[14] H. C. C., Maduka, A. N. Okpogba, C. E. Ugwu, C. C. Dike, P. N. Ogueche, D. T. Onwuzurike, D. C. Ibe (2014). Phytochemical, antioxidant and microbial inhibitory effects of Spondias mombin leaf and stem bark extracts. Journal of Pharmaceutical and Biological Sciencess 9, 14-17.

[15] D. K. Pradhan, A. K. Panda, R. K. Behera, S. Jha, M. R. Mishra, A. Mishra, S. Chondhary (2013). Ethno medicinal and therapeutic potential of Sida acuta. International Research Journal of Pharmacy 4, 88-92. 